\title{
Project of being, severe illness and death: an existentialist understanding of the end-of-life experience
}

\begin{abstract}
According to sartrean existentialism, freedom defines the human subject, since choices place them before a field of possibilities of being; always directing them to the future, to what the individual is not yet. In this sense, since the human condition always demands an after, there is no place for death. In the ontological dimension of the human being, death is, therefore, the negation of existence and of all projects. However, if there is a situation that concretely places the subject before it, such as organic illness, death will be experienced as a personal possibility. This new condition of being in the world may impose on the subject a reformulation of the meaning they have given to their existence. By aiming at the struggle for their permanence in the world, they will have to accept the condition imposed by the illness and reformulate their project based on this new experience of being. In order to do so, the senses or meanings socially, culturally and historically shared will provide them with the basis for their understanding of themselves and the world and will eventually impose themselves as the horizon for them to organize themselves psychically. Again, they will have to choose, between the existing understandings in their context, based on their sociological mediations and psychological possibilities, the senses chosen for the end of their life. Understanding the psychological relations the subject might have with death is, therefore, critical to the various disciplines in the area of health, because it seeks to provide the subject with possibilities of still accomplishing their project, from the different existential conditions and horizons, by understanding that the experiences of suffering affect them in all their history and complexity.
\end{abstract}

Keywords: death, psychology, project of being, existential psychology, jean-paul sartre
Volume I Issue 5 - 2017

\author{
Fabíola Langaro,' Daniela Ribeiro Schneider² \\ 'Graduate Program in Psychology, Federal University of Santa \\ Catarina, Brazil \\ ${ }^{2}$ Department of Psychology, Federal University of Santa \\ Catarina, Brazil
}

\begin{abstract}
Correspondence: Fabíola Langaro, Universidade Federal de Santa Catarina, Rua Des. Desembargador Vitor Lima, Caixa postal 476, Sala 214 - Bloco D - CFH, Trindade, Florianópolis SC, CEP 88.040-400, Brazil, Tel +55 48372 I - 8607, Email flangaro@hotmail.com
\end{abstract}

Received: September 12, 2017 | Published: November 03, 2017

\section{Introduction}

For sartrean existentialism ${ }^{1-3}$ in ontological terms, freedom defines the subjects' being, considering that they are defined by their choices and by the actions arising from them, always open to "becoming". Thus, the future, while appearing on the horizon to announce to the subject what it is, based on what will still be, also characterizes the subject in their possibility of not being. In this direction, subjects are constituted based on their choices and actions, which are always related to a project of being. There is no individual without a project, since not having a project is still having a project, because in each positioning, in each behavior of the subject there is a meaning that transcends them; each concrete and empirical choice designates a fundamental choice, that is, the realization of the project of being. ${ }^{4}$

The project is nothing but the desire to be a certain type of person, with specific characteristics and qualities that establish certain social relations. For Sartre ${ }^{2,3}$ the subject is defined by their project, since their actions aim to overcome the condition that is given to them, revealing and determining their situation. In this sense, the future, while appearing on the horizon to announce to the subject what they are, based on what will still be, also characterizes the subject in their possibility of not being such future, since the Future is not, the Future is made possible. Future is the continuous possibility of the possible. ${ }^{1}$

In this sense, the power of being is given by the future. Therefore, being can only be realized, insofar as it is directed towards what is not yet, toward its future to be realized. From this, it follows that there is no place for death in the being of the subject. That is, death appears not as a possibility, but as the nothingness of my possibilities. ${ }^{1}$ In the ontological dimension of the human being, death is therefore absurd, since it is the negation of existence and of all projects.

\section{Discussion}

Although it is ontologically understood as impossibility, there is no way to indefinitely reject death as fact. No matter how much it may be thought as something external, not within the reach of the being of the subject, at some point the subject will realize that no one can die for them, since it is an event of the human life. Thus, death is a human phenomenon, the last of life, but still life1. From this perspective, it is not possible to expect death. However, if there is a situation that concretely casts the subject into it, such as an illness of the body or severe psychic suffering, it will be experienced as a personal possibility, even if it is external. There is a character of facility, a radical contingency in it. ${ }^{1,5}$

Not being free to die, the subject is a free mortal. Faced with the concrete possibility of death, the subject, in psychological terms, may feel the need to make sense of their life and death. For this purpose, in relation to their anthropological dimension, they will use socially, culturally and historically shared senses or meanings and organize themselves psychically based on them. They will choose, among many existing understandings and according to their 
psychological possibilities, meanings for the end of their life. Thus, it cannot be said that death gives life a meaning that comes from the outside: meaning can only derive from subjectivity itself. ${ }^{1}$

Viktor Frankl ${ }^{6,7}$ an existentialist known for his theory focused on the meaning of life, considers that a person, even on the verge of death, can find a meaning for suffering, which would give them conditions to cope while maintaining their emotional and psychological integrity. This condition, according to the author, would be possible based on life experiences and by maintaining some perspective of future, since what paralyzes the individual is not suffering itself, but meaningless suffering.

In the Franklian ${ }^{6,7}$ perspective meaning is connected to life as a whole, and many times, it is exactly at the end of life that one's trajectory may find its meaning. The author mentions that, just as a book or a movie only make sense when they come to an end, life would only have its broad meaning understood and elaborated at its end. For this reason, it might be common that, with the imminence of death, people start valuing each day still to be lived and the possibility of continuing their project of being. The awareness of their finitude and the imminence of their physical death may bring a sense of urgency to manage the remaining time, in order to close their life cycle with the least possible pending issues and implement everything that is still important. Thus, understanding the factual character of death may push the subject to make authentic choices while alive, based on their desire of being.

In this way, in order to fight for their permanence as a being in the world, due to situations such as severe illness, which will inexorably lead to death, the subject will have to understand the condition imposed by the illness and reformulate their project based on this new experience of being. Since it is a project, they will be faced with the need to choose within a field of possibilities in which there are elements that the subject, until then, did not know - elements that question and escape them. Furthermore, the subject begins to experience a condition that is culturally and socially permeated by silence, which family members, friends and health teams often avoid mentioning, out of fear, prejudice or ignorance, usually creating an atmosphere of secrets and sufferings.

Therefore, this process of reformulating the project of being will be circumscribed, not only by the history built by the subjects throughout their existence and their psychological dynamics, but also by the mediations to which they are exposed at the time of their illness and death process and, therefore, by the field of possibilities that lie ahead of them. In this context, it is very important to offer and expand possibilities, so that the subject may accomplish their wishes, considering the different existential conditions and horizons imposed by the disease, including death, understanding that the experiences of suffering affect them throughout their history and complexity.

\section{Conclusion}

In view of the above, we conclude that understanding a subject's psychological relations with death is critical to the various disciplines in the health area. In this context, the main objective of studies related to death based on existential-phenomenological psychology is to offer possibilities for the subject to resignify their project of being, still trying to accomplish their wishes and value significant social mediations, based on the different relational contexts, by understanding that the experiences of suffering affect them throughout their history and existential complexity, providing subsidies for the work of the psychologist in palliative healthcare. It is also possible to relieve the suffering of such patients if health professionals create conditions for them to construct and find meaning for their existence, so that they can peacefully accept death as fact, and therefore, as the human condition. Thus, talking about death leads us to make choices for/in life.

\section{Acknowledgements}

None.

\section{Conflict of interest}

The author declares no conflict of interest.

\section{References}

1. Sartre JP. Being and nothingness. 14th ed. Vozes, Petrópolis, Brazil: Springer; 1997. p. 1-691.

2. Sartre JP. Existentialism is a humanism. Abril Cultural, Coleção Os Pensadores, São Paulo, Brazil: Springer; 1978a. p. 1-11.

3. Sartre JP. The Problem of Method.Abril Cultural, Coleção Os Pensadores, São Paulo, Brazil: Springer; 1978b.

4. Schneider DR. Sartre e a Psicologia Clínica. Florianópolis, Editora da UFSC, Brazil: Springer; 2011. 290 p.

5. Sartre JP. The wall. Nova Fronteira, Rio de Janeiro, Brazil: Springer; 1982.

6. Frankl VE. The Will to Meaning: Foundations and Applications of Logotherapy. 1st ed. São Paulo, Brazil: Springer; 2011.

7. Frankl VE. Psicoterapia e sentido da vida. 4th ed. Quadrant, São Paulo, Brazil: Springer; 2003. 352 p. 